\title{
Influence Of Capital Funds, Infrastructure Means, And Professionalism Human Resources On Service Quality And Patient Satisfaction Of Puskesmas District Polewali Mandar West Sulawesi
}

\author{
Sriharni Patandianan \\ University doctoral student, August 17, 1945, Surabaya, Indonesia \\ Tri Ratnawati \\ University lecturer, August 17, 1945 Surabaya, Indonesia \\ Sigit Sardjono \\ University lecturer, August 17, 1945, Surabaya, Indonesia
}

\begin{abstract}
Social security is a Universal Declaration of Human Rights as well as nationally (the 1945 Constitution and various other laws and regulations). The problems that often arise in relation to the BPJS tariff that has been determined in accordance with the Regulation of the Minister of Health of the Republic of Indonesia Number 69 Year 2013 on the Health Service Tariff Standard At First Level Health Facilities And Health Facilities Continued Level In The Implementation of Health Insurance Program. The fulfillment of access to health services, then the community of JKN users began to pay attention to the quality of service shown by their satisfaction to receive services from BPJS Health faskes. Based on the results of interviews with BPJS Health Branch Office of Polewali Mandar district obtained data regarding the complaints of JKN participants in FKTP in Polewali Mandar District include less friendly service, less informative, long queues, rejection of patients outside the region and unserved patients for medical treatment outside FKTP working hours. This is an indication of problems in patient satisfaction JKN while patient satisfaction is one of the target in the implementation of JKN program. This study aims to analyze the effect of Capitation Fund on service quality, analyze the effect of Kapuas Fund on patient satisfaction, analyze the effect of infrastructure facilities on service quality, analyze the influence of infrastructure facilities on patient satisfaction, analyze the influence of professionalism HR on service quality, analyze the influence of professionalism HR toward satisfaction patients, and analyzed the effect of service quality on patient satisfaction of Puskesmas in Polewali Mandar regency of West Sulawesi.
\end{abstract}

Key word: capital funds, infrastructure, HR professionalism, service quality and Patient satisfaction

\section{INTRODUCTION}

Health services are any effort that is carried out individually or jointly within an organization to maintain and improve health, prevent and cure diseases and restore the health of individuals, families, groups or communities (Azwar, 1997: 58). A common problem faced by Puskesmas and hospitals is that they have not been able to provide something that service users really want. The main factor is because the services provided are of low quality so that they can not produce the service the patient hopes.

Social security is a Universal Declaration of Human Rights as well as nationally (the 1945 Constitution and various other laws and regulations). The Social Security Law is in the 
framework of the implementation of the provision of the right to social security as a human right as contained in Article $28 \mathrm{H}$ paragraph (3) of the 1945 Constitution: "Every person shall have the right to social security which enables his complete development as a mankind" on social security is a constitutional right for all Indonesian people to be met by the state.

In accordance with information obtained from a patient that the service received when visiting the health center is a service whose procedures have been established through the rules and announcements posted on public places. From the information indicates that the district health office Polewali Mandar through Puskesmas as UPTD has shown the ability to make adjustments to the rules set nationally to be re-reformulated into the form of implementation rules in accordance with the conditions and needs of the community. This ability is termed by self-modifying power derived from its ability to organize and execute various authorities in positions as elements of the implementation of local government in the field of health services (Syamsuddin in Nugroho, 2000: 13-14).

The system of financing of health services in family doctor concept is done through insurance. With the capitation system is considered more effective and efficient in reducing the morbidity rate than the fee-for-service system that is currently in effect. The capitation system is a system of per capita health service payments made in advance (Moeloek, 2004: 76).

The fulfillment of access to health services, then the community of JKN users began to pay attention to the quality of service shown by their satisfaction to receive services from BPJS Health faskes. Based on the results of interviews with BPJS Health Branch Office of Polewali Mandar district obtained data regarding the complaints of JKN participants in FKTP in Polewali Mandar District include less friendly service, less informative, long queues, rejection of patients outside the region and unserved patients for treatment outside working hours FKTP. This is an indication of problems in patient satisfaction JKN while patient satisfaction is one of the target in the implementation of JKN program.

Based on some of the problems above, this research needs to be done to know the level of satisfaction of JKN patient at FKTP first level health facility especially at FKTP owned by Polewali Mandar regency government, membership status and socio demographic characteristic with JKN patient satisfaction toward primary health service at FKTP considering JKN program is a new program, where BPJS health program launches primary service optimization with patient satisfaction is the target that will be achieved in the development of JKN program.

\section{Capital Funds}

\section{LITERATURE REVIEW}

Presidential regulation Number 32 Year 2014 States that capital funds is the magnitude of payments per month which is paid upfront to the FKTP based on the number of participants who are registered regardless of the type and quantity of medical services provided. Kapitasi fund management is budgeting procedures, implementing, administering and accountability kapitasi funds received by the BPJS from FKTP health. BPJS health collects dues paid by the people who have listed themselves as participants of the national health assurance program (JKN). Next the BPJS Health distribute budget guarantees the health of society as a capital to optimize the service. The term capital comes from the word capital means head. Performance indicators applied by at health centers, namely: 1). Indicators of communication contact number of participants 2). The ratio of References to Non including specialised 3). The number of participants to Transfer Another FKTP 4). Prolanis Ratio FKTP. 


\section{Infrastructure}

Moenir (1992:119) facilities and infrastructure is a set of tools that are used in a process of activities both those tools is the main equipment or auxiliary gear, both of which serve to materialize the goals achieved. Based on the above understanding, then the infrastructure basically have the main functions and infrastructure are as follows: 1 . Speed up the process of implementation of the work so as to save time. 2. Improve productivity, both goods and services. 3. The work of higher quality and guaranteed. 4. Easier/simpler in the motion of the user/abuser. 5. Precision of the order of stability of workers more secure. 6. Give rise to a sense of comfort to those concerned. 7. Give rise to complacency at those interested parties who use it. Indicators of health clinics on infrastructure (2001), namely: 1) The condition of the building of clinics, 2) Availability of electricity, 3) Health Tool, 4) Sanitation Systems and 5) Availability of means of transport

\section{Professionalism of Human Resources}

Professionalism as a social contract is also mentioned in the Standards of medical Competence Indonesia 2012. Brennan, et al, 2002:69) stated that professionalism is the basis of the social contract. The doctor is required to put the interests of patients above their own interests, establish and maintain standards of competence and integrity, as well as providing community health problem solving. It is very important for this is a trust contract (Brennan, et al, 2002; Cruess S.R. Cruess R.L., 2009).

The social contract is simply not written, but there are some social contract in writing subject to the country of the place of refuge that profession. The social contract is written can be found in the laws and Government regulations concerning medicine, legislation regarding the health care system, the decisions of the law found in the jurisprudence, as well as the code of ethics set forth by that profession on its own. Health care systems and policies issued by the Government is an external influence to the social contract. This is evident with the current field. Poor health care system given by a health institution will affect the opinions of the community against doctor. Dwiyanto (in Pasolong, 2006:50-51) concerning the indicators used to measure professionalism that is as follows: 1) productivity, 2) quality of the services, 3) Responsiveness, 4) corporate responsibility and 5) accountability,.

\section{Service Quality}

Parasuraman (Kheng et al. 2010) mention that service means the degree of differences arising from service of process and the interaction between the provider service with the consumer. Problems about the service now received greater attention from many organizations ranging from regional, national organizations up to global organizations, and is regarded as a tool that can affect revenue streams an organization or the company. The quality of service has been conceptualized as the difference between the expectations of the customer regarding the services that will be accepted and the perception of the service received. Service quality is a concept.

Kotler and Keller (2009:89) satisfaction is feeling happy or disappointed someone arising because of the perceived performance compare products (or results) against their expectations. Zeithaml and Bitner (2000:75) definition of satisfaction were: Response or responses about meeting consumer needs. Satisfaction is an assessment regarding the characteristics or the specialty products or services, or the products themselves, which provide consumer enjoyment level related to the fulfillment of the needs of consumer consumption. This satisfaction of consumer behavior. Consumer behavior is defined as an act that directly 
received by the consumer in obtaining, consume and wear of products or services, including the decision process that preceded the action.

\section{Patient Satisfaction}

Mathew (2010:42) argues that the satisfaction of the patient can be assessed based on the interpretation of the patient against the received service is in compliance with their expectations as the completeness of facilities and infrastructure, friendliness and courtesy officer providing services as well as the skills of the officers at the time of the service. Rashid and Amina (2014:34) view that satisfaction can be divided into two kinds, i.e., the intangible satisfaction is satisfaction which can be felt and seen by clients as well as have been utilized, and satisfaction of a psikologica does not materialize from the delivery health but can be felt by the patient.

Kotler (2002:104) there are indicators to measure patient satisfaction. 1 . The system of complaints and suggestions boxes with the provision of advice, hotline service, and others that provide opportunities to customers or patients in presenting complaints, suggestions and comments are the opinions of the customers. 2. Ghost shopping (the mysterious shopper) by hiring some people as a patient or a buyer of products reported his findings so that it can be used as consideration by an organization for decision-making. 3. Lost customer analysis by contacting customers who have quit or switch to another health kelayanan so that it is known to cause so that organizations can take a decision in the next refinement. 4. Survey of customer satisfaction by conducting surveys and research on customer satisfaction through questionnaires, interviews, telephone or direct mail.

\section{Research Hypothesis}

1. Capitation Fund Puskesmas significantly influence service quality of Puskesmas in Polewali Mandar district, West Sulawesi.

2. Puskesmas Capitation Fund has a significant effect on patient satisfaction of Puskesmas in Polewali Mandar district of West Sulawesi.

3. The infrastructure facilities have a significant effect on service quality of Puskesmas in Polewali Mandar district of West Sulawesi.

4. The infrastructure facilities have a significant effect on the satisfaction of the Puskesmas patient in Polewali Mandar district, West Sulawesi.

5. Professionalism of human resources has a significant effect on the service quality of Puskesmas in Polewali Mandar district, West Sulawesi.

6. Professionalism of human resources has a significant effect on patient satisfaction of Puskesmas in Polewali Mandar district of West Sulawesi.

7. Service quality has a significant effect on patient satisfaction of Puskesmas in Polewali Mandar district, West Sulawesi. 


\section{Analysis Model}

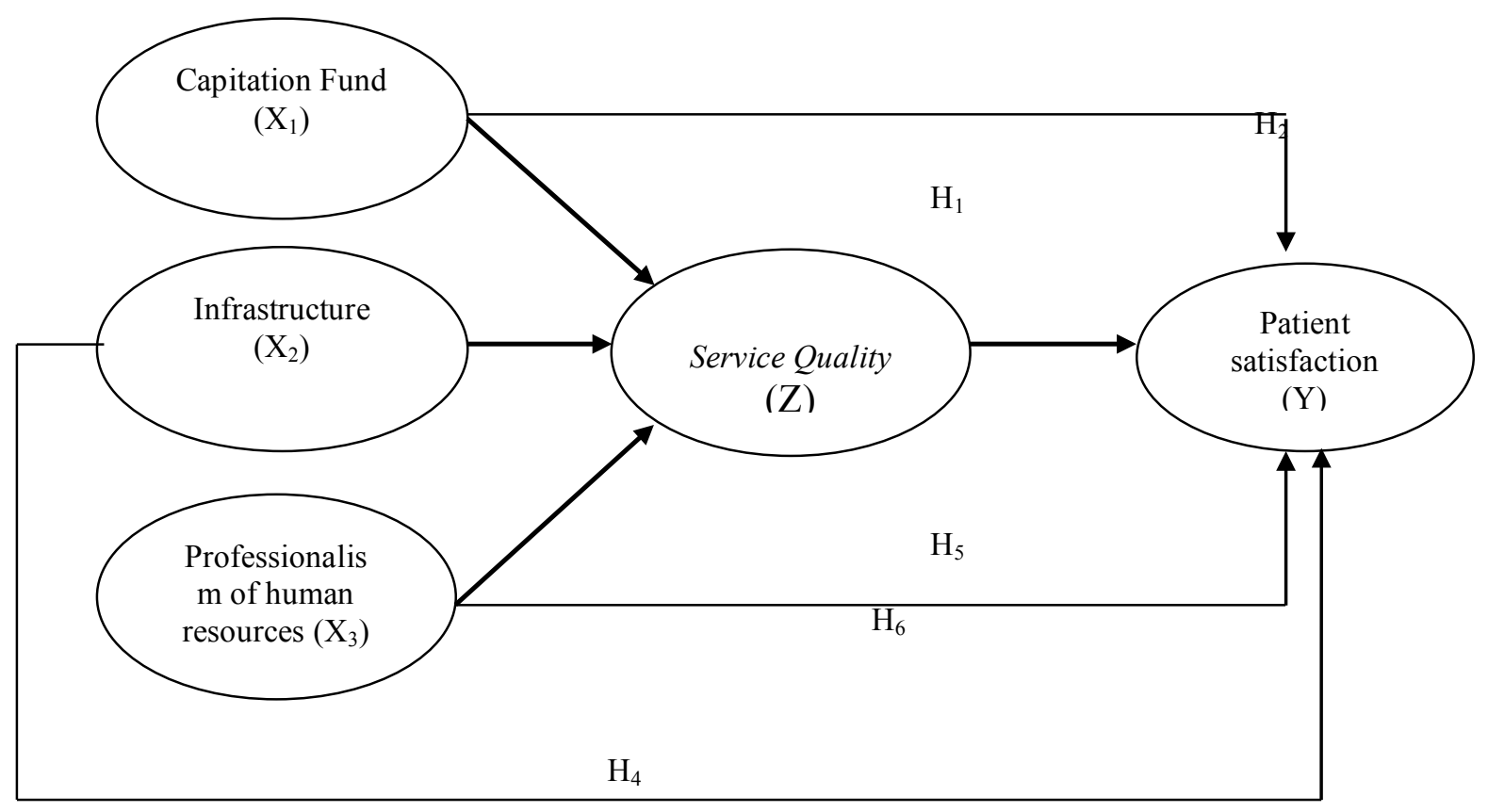

Figure 1. Analysis Model

\section{Research design}

\section{RESEARCH METHODS}

According to Nasir (2003: 9) suggests the design of research or research design is all the necessary processes in planning and implementation research. On the basis of this understanding, associated with the purpose of research, this research includes the type of explanatory research (explanatory research). Includes explanatory survey research because the researcher want to explain the causal relationship between free variables capitation fund, human resources infrastructure and professionalism, its influence to service quality as intervening variable and its impact on patient satisfaction of Puskesmas of Polewali Mandar Regency of West Sulawesi Province as dependent variable. Number of target population in this study were 665 participants. The sampling technique is done by using proportional random sampling method (proportional sample technique) by referring to the formula put forward by Slovin in Umar (1999) to 250 responden.

The variables in this study were divided into three groups of variables, the first independent variable (exogenous construct) consisting of capitation funds, infrastructure, and HR professionalism, the two dependent variables (endogenous constructs) in this study are patient satisfaction and intermediate variables (construct intervening) in this research is service quality.

\section{Data analysis technique}

Based on conceptual framework and research design that was built, this research use SEM analysis technique (Structural Equation Modeling) through AMOS 20.01 program, Ferdinand (2002: 40). This analysis tool is chosen because by using SEM method will be able to know the influence of a variable either directly or indirectly to other variables simultaneously. Other SEM advantages, influence analysis does not connect variables but between indicators of other variables. Complete SEM modeling basically consists of Measurement Model and Structural Model, Sharma (1996: 122). The Measurement Model is intended to confirm the dimensions 
developed on a factor. While the Structural Model is a model of the relationship structure that forms or explains causality between factors.

\section{RESULTS AND DISCUSSION}

After the measurement model is met the next stage is a structural model. Stage structural model function to ensure the model has been in accordance with the data and ensure the presence or absence of influence between variables studied. In structural testing this model also uses the Maximum Likelihood Estimation (MLE) model estimation. At this stage the first thing to do is make sure that the model has been in accordance with the data or the model has been fit. Then if the model has been fit then hypothesis testing can be done. The result of structural model estimate analysis is presented.



Figure 2.Full Structural Model

The results show that all goodness of fit criteria have given a fit index. Furthermore, it will be followed by testing the reliability of SEM model and hypothesis testing.

Table 1. Evaluation Criteria Goodness of Fit Indices

\begin{tabular}{|c|c|c|c|}
\hline Goodness of Fit Measure & Results Model & Cut off & Description \\
\hline $\begin{array}{c}\text { Probabilitas } \\
\mathrm{X}^{2} \text { Chi Square }\end{array}$ & 0,141 & $\geq 0,05$ & Fit \\
\hline Cmin/DF & 1,102 & $\leq 2,00$ & Fit \\
\hline RMSEA & 0,020 & $\leq 0,08$ & Fit \\
\hline GFI & 0,924 & $\geq 0,90$ & Fit \\
\hline AGFI & 0,905 & $\geq 0,90$ & Fit \\
\hline TLI & 0,992 & $\geq 0,95$ & Fit \\
\hline CFI & 0,993 & $\geq 0,95$ & Fit \\
\hline
\end{tabular}

The results show that all goodness of fit criteria have given a fit index. Furthermore, it will be followed by testing the reliability of SEM model and hypothesis testing. The results of the analysis of the relationship of causality between the variables research using program AMOS version 20 can be seen in table 2 . 
Patandianan, S., Ratnawati, T., \& Sardjono, S. (2018). Influence Of Capital Funds, Infrastructure Means, And Professionalism Human Resources On Service Quality And Patient Satisfaction Of Puskesmas District Polewali Mandar West Sulawesi. Archives of Business Research, 6(2), 10-18.

Table 2. Test Causality Regression Weight

\begin{tabular}{|c|c|c|c|c|c|c|}
\hline \multicolumn{3}{|c|}{ The Relationship of Causality } & $\begin{array}{c}\text { Std. } \\
\text { Estimate }\end{array}$ & C.R. & $\begin{array}{c}P \\
\text { Value }\end{array}$ & Description \\
\hline Capitation fund $\left(\mathrm{X}_{1}\right)$ & $\rightarrow$ & Service Quality (Z) & 0,505 & 7,390 & 0,000 & Significant \\
\hline Capitation fund $\left(\mathrm{X}_{1}\right)$ & $\rightarrow$ & $\begin{array}{c}\text { Patient Satisfaction } \\
\text { (Y) }\end{array}$ & 0,364 & 4,711 & 0,000 & Significant \\
\hline Infrastructure Means $\mathrm{X}_{2}$ ) & $\rightarrow$ & Service Quality (Z) & 0,348 & 5,215 & 0,000 & Significant \\
\hline $\begin{array}{l}\text { Infrastructure Means } \\
\qquad\left(\mathrm{X}_{2}\right)\end{array}$ & & $\begin{array}{l}\text { Patient Satisfaction } \\
\text { (Y) }\end{array}$ & 0,129 & 1,930 & 0,054 & $\begin{array}{c}\text { No } \\
\text { Significant }\end{array}$ \\
\hline Professionalism HR $\left(\mathrm{X}_{3}\right)$ & $\rightarrow$ & Service Quality (Z) & 0,278 & 4,359 & 0,000 & Significant \\
\hline Professionalism HR $\left(\mathrm{X}_{3}\right)$ & & $\begin{array}{c}\text { Patient Satisfaction } \\
\text { (Y) }\end{array}$ & 0,251 & 3,873 & 0,000 & Significant \\
\hline Service Quality (Z) & & $\begin{array}{c}\text { Patient Satisfaction } \\
\text { (Y) }\end{array}$ & 0,322 & 3,607 & 0,000 & Significant \\
\hline
\end{tabular}

\section{Effect of Capitation Fund on Service Quality}

The results of hypothesis testing using SEM method with the help of AMOS 20.0 Software proves that capitation fund significantly influence the quality of Puskesmas service in Polewali Mandar district, West Sulawesi. Significant causality test results between capitation funds on service quality are shown with p-value of $0,000 \leq 0.05$. The amount of influence of capitation fund on service quality is 0,505 (positive). With this result, the research hypothesis which states that capitation funds have a significant effect on the quality of Puskesmas service in Polewali Mandar district of West Sulawesi, is acceptable.

\section{Effect of Capitation Fund on Patient Satisfaction}

The result of hypothesis testing using SEM method with the help of AMOS 20.0 Software proves that capitation fund also have a significant effect on patient satisfaction of Puskesmas in Polewali Mandar district of West Sulawesi. Significant causality test results between capitation funds on patient satisfaction is shown with p-value of $0.000 \leq 0.05$. The magnitude of the effect of capitation funds on patient satisfaction is 0.364 (positive) With this result, the research hypothesis which states that capitation funds have a significant effect on patient satisfaction of Puskesmas in Polewali Mandar district, West Sulawesi, is also acceptable.

\section{Effect of Infrastructure Means on Service Quality}

The results of hypothesis testing using SEM method with the help of AMOS 20.0 Software proves that the infrastructure also has a significant effect on the quality of Puskesmas service in Polewali Mandar district, West Sulawesi. Significant causality test results between means of infrastructure to service quality is shown with p-value of $0,000 \leq 0.05$. The magnitude of infrastructure impact on service quality is 0.348 (positive). With this result, the research hypothesis stating that infrastructure facilities have a significant effect on the quality of Puskesmas service in Polewali Mandar district, West Sulawesi, is also acceptable.

\section{Effect of Infrastructure Facility to Patient Satisfaction}

The results of hypothesis testing using SEM method with the help of AMOS 20.0 software proved that the infrastructure did not significantly affect the satisfaction of Puskesmas patient in Polewali Mandar district, West Sulawesi. The result of insignificant causality test between means of infrastructure to patient satisfaction is shown with p-value of $0.054>0.05$. The amount of influence of infrastructure facilities on patient satisfaction is only 0.129 . With this result, the research hypothesis stating that infrastructure facilities have a significant effect on patient satisfaction of Puskesmas in Polewali Mandar district, West Sulawesi, is unacceptable. 


\section{Effect of Professionalism HR Service Quality}

The results of hypothesis testing using SEM method with the help of AMOS 20.0 Software proves that HR professionalism also has a significant effect on the quality of Puskesmas service in Polewali Mandar district, West Sulawesi. The result of significant causality test between HR professionalism on service quality is shown with p-value of $0.000 \leq 0,05$. The amount of influence of HR professionalism on service quality is 0.278 (positive). With this result, the research hypothesis stating that HR professionalism has a significant effect on the quality of Puskesmas service in Polewali Mandar district, West Sulawesi, is also acceptable.

\section{Effect of Professionalism HR Patient Satisfaction}

The results of hypothesis testing using SEM method with the help of AMOS 20.0 Software proves that HR professionalism also has a significant effect on patient satisfaction of Puskesmas in Polewali Mandar district of West Sulawesi. The result of significant causality test between HR professionalism toward patient satisfaction is shown with p-value of $0.000 \leq 0,05$. The amount of influence of HR professionalism on patient satisfaction is 0.251 (positive). With this result, the research hypothesis stating that HR professionalism has a significant effect on patient satisfaction of Puskesmas in Polewali Mandar district, West Sulawesi, is also acceptable.

\section{Effect of Service Quality on Patient Satisfaction}

The results of hypothesis testing using SEM method with the help of AMOS 20.0 Software proves that the quality of service also significantly influence the satisfaction of Puskesmas patient in Polewali Mandar district, West Sulawesi. Significant causality test results between the quality of service to patient satisfaction is shown with $p$-value of $0.000 \leq 0.05$. The amount of influence of service quality to patient satisfaction is 0.322 (positive). With this result, the research hypothesis.

\section{Conclusion}

\section{CONCLUSIONS AND SUGGESTION}

The results of this study generally can be concluded that Puskesmas capitation fund has an effect on service quality and patient satisfaction of BPJS participants registered at Puskesmas in Polewali Mandar district of West Sulawesi, thus Hypothesis $1\left(\mathrm{H}_{1}\right)$, and Hypothesis $2\left(\mathrm{H}_{2}\right)$ is acceptable. The infrastructure facilities affect the service quality of BPJS participants registered at the existing health center in Polewali Mandar district of West Sulawesi, thus Hypothesis 3 $\left(\mathrm{H}_{3}\right)$ is acceptable, while the effect on patient satisfaction is not significant, so Hypothesis 4 $\left(\mathrm{H}_{4}\right)$ is unacceptable. HR professionalism has an effect on service quality and satisfaction of BPJS participant registered at Puskesmas in Polewali Mandar district of West Sulawesi, thus Hypothesis $5\left(\mathrm{H}_{5}\right)$, and Hypothesis $6\left(\mathrm{H}_{6}\right)$ is acceptable. While the quality of service also affects the satisfaction of patients participating BPJS registered at the existing Puskesmas in Polewali Mandar district of West Sulawesi, thus Hypothesis $7\left(\mathrm{H}_{7}\right)$ is acceptable.

\section{Suggestions}

To the Puskesmas in Polewali Mandar district of West Sulawesi, it is expected that:

a. Increase the Puskesmas Capacity Fund primarily through improving the proline ratio by encouraging hypertensive and high blood sugar patients to follow prolanic gymnastics, providing counseling to patients following prolanic gymnastics, and always checking patients periodically after doing proline exercises.

b. Provision of complete and feasible infrastructure, especially through the availability of health equipment, by completing the availability of health equipment, and rearranging health equipment to be more neatly arranged.

e. Increase patient's satisfaction, especially through easy access of services, by facilitating 
entrance to Puskesmas, improving spatial arrangement, and providing complete information service.

\section{BIBLIOGRAPHY}

Askes PT, 2002, Guidelines for participants of Askes social, Jakarta: PT (Persero) Indonesia health insurance.

Azwar, A. 2007. Maintaining The Quality Of Health Services Application Of The Principle Of The Circle Problem Solving. Pustaka Sinar Harapan. Jakarta.

Cruess RL., Cruess SR., Steinert Y., 2009. Principles for Designing a program for Teaching and Learning of Professionalism at the Undergraduate Level in Teaching Medical Professionalism ed., Cruess RL., Cruess SR., Steinert Y. NewYork: Cambridge University Press.

Departemen Kesehatan RI, 2008, The Organization of public health assurance program (Jamkesmas), Jakarta: Secretary General of the Ministry of health of INDONESIA.

Departemen Kesehatan RI, 2008, Petunjuk teknis jaminan kesehatan masyarakat (Jamkesmas) di puskesmas dan jaringannya tahun 2008, Jakarta : Direktorat Jenderal Bina Kesehatan Masyarakat.

Dwiyanto, Agus 2006,. Embody Good Geovernance Through The Ministry Of Public. Yogyakarta: UGM Press.

Ferdinand, Augusty. 2002. Structural Equation Modelling in Research Management. Semarang:FE UNDIP.

Julia, Brannen.2002. Qualitative and quantitative Research Guide. Yogyakarta: Pustaka Pelajar

Kemenkes RI, 2013. Regulation of the Minister of health of the Republic of Indonesia Number 71 Year 2013 About health care On the national health coverage.

Kotler, Amstrong. 2001. Principles of marketing, Twelfth Edition, Jilid 1. Jakarta: Erlangga

Kotler dan Keller. 2009. Marketing Management. Chapter I. Edition 13. Jakarta: Erlangga. 